\title{
Synthesis, structures, magnetism and electrochemical properties of triruthenium-acetylide complexes
}

\author{
Ching-Kuo Kuo, ${ }^{a}$ Jung-Che Chang, ${ }^{b}$ Chen-Yu Yeh, ${ }^{* b}$ Gene-Hsiang Lee, ${ }^{a}$ Chih-Chieh Wang ${ }^{c}$ \\ and Shie-Ming Peng*a,d \\ a Department of Chemistry, National Taiwan University, Taipei, Taiwan \\ ${ }^{b}$ Department of Chemistry, National Chung Hsing University, Taichung, Taiwan \\ ${ }^{c}$ Department of Chemistry, Soochow University, Taipei, Taiwan \\ ${ }^{d}$ Institute of Chemistry, Academia Sinica, Taipei, Taiwan.E-mail: smpeng@ntu.edu.tw
}

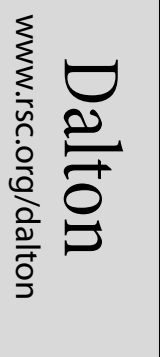

Received 6th May 2005, Accepted 5th August 2005

First published as an Advance Article on the web 2nd September 2005

A series of triruthenium complexes with arylacetylide axial ligands $\mathrm{Ru}_{3}(\mathrm{dpa})_{4}\left(\mathrm{C}_{2} \mathrm{X}\right)_{2}\left(\mathrm{BF}_{4}\right)_{y}(\mathrm{dpa}=$ dipyridylamido; $\mathrm{X}=\mathrm{Fc}, y=0$ (1); $\mathrm{X}=\mathrm{Ph}, y=0(2) ; \mathrm{X}=\mathrm{PhOCH}_{3}, y=1$ (3); $\mathrm{X}=\mathrm{PhC}_{5} \mathrm{H}_{11}, y=1$ (4); $\mathrm{X}=\mathrm{PhCN}, y=0(5) ; \mathrm{X}=$ $\mathrm{PhNO}_{2}, y=0$ (6)) have been synthesized. The crystal structures show that the $\mathrm{Ru}-\mathrm{Ru}$ bond lengths (2.3304(9)2.3572(5) $\AA$ ) of these compounds are longer than those of $\mathrm{Ru}_{3}(\mathrm{dpa})_{4} \mathrm{Cl}_{2}(\mathrm{Ru}-\mathrm{Ru}=2.2537(1) \AA)$. This is ascribed to the formation of the stronger $\pi$-backbonding from metal to axial ligand which weakens the $\mathrm{Ru}$-Ru interactions and the bond order is reduced in the triruthenium unit. Cyclic voltammetry and differential pulse voltammetry show that compound 1 exhibits electronic coupling between the two ferrocenyl units with $\Delta E_{1 / 2}$ close to $100 \mathrm{mV}$. Compounds 2-6 display three triruthenium-based reversible one-electron redox couples, two oxidations and one reduction, and the electrode potentials shift upon varying the substituents. A linear relationship is observed when the Hammett constants are plotted against the redox potentials.

\section{Introduction}

Mononuclear and dinuclear complexes with acetylide ligands have been extensively investigated since the acetylide complexes exhibit interesting redox and spectroscopic properties. ${ }^{1,2}$ Examples of multinuclear complexes with acetylide ligands are rare although numerous multinuclear metal string complexes have been synthesized in the past decade. ${ }^{3,4}$ Interest in the multinuclear metal complexes arises from an understanding of the metalmetal interactions in these complexes and their potential use as "molecular wires". To be considered as molecular wires, the molecules have to be able to show strong electronic coupling and to provide a pathway for electrons. Our previous studies show that some of our linear multinuclear metal complexes exhibit strong metal-metal interactions. ${ }^{3}$ To test the communicating ability of these complexes, we recently reported their electron transfer efficiency at single molecular level by using the STM (scanning tunnelling microscopy) methodology. ${ }^{5}$ The results showed that the electron transfer efficiency is dependent on the metal-metal bond order. Another convenient way to evaluate the electron conduction capability is to look at the electronic communication between the redox-active termini bonded to the ends of a molecular wire. ${ }^{6}$ Our previous studies on the triruthenium complex showed that there is an overall bond order of three over the $\mathrm{Ru}_{3}$ unit. Thus, the triruthenium is a suitable candidate for use as a molecular wire. ${ }^{7}$ We report here the synthesis and structures of a series of triruthenium-based molecular wires with two redox-active ferrocenylacetylides or arylacetylides at the ends, and the electrochemical properties of these complexes (Scheme 1). The use of carbon-carbon

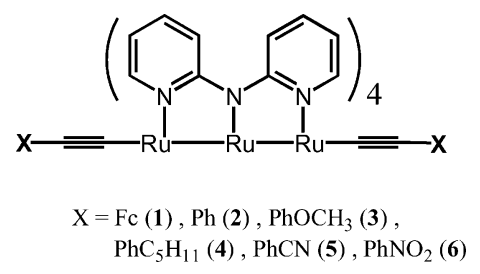

Scheme 1 triple bonds facilitates the electronic communication between the triruthenium core and the aryl groups and increases the substituent effects to the trirutheniumn core.

\section{Experimental}

\section{General}

All reagents and solvents were obtained from commercial sources and were used without further purification unless otherwise noted. THF was distilled over $\mathrm{Na}$ /benzophenone under a $\mathrm{N}_{2}$ atmosphere prior to use. $\mathrm{CH}_{2} \mathrm{Cl}_{2}$ and $\mathrm{CH}_{3} \mathrm{CN}$ were dried over $\mathrm{CaH}_{2}$ and freshly distilled prior to use. Tetra-nbutylammonium perchlorate (TBAP) was recrystallized twice from ethyl acetate and further dried under vacuum. $\mathrm{Ru}_{3}(\mathrm{dpa})_{4} \mathrm{Cl}_{2}$ $(\mathrm{dpa}=$ dipyridyylamido $)$ and $4-\mathrm{CN}-\mathrm{C}_{6} \mathrm{H}_{4}-\mathrm{C} \equiv \mathrm{CSi}(\mathrm{Me})_{3}$ were prepared according to previously reported methods. ${ }^{8}$

\section{Physical measurements}

Absorption spectra were recorded on Hewlett Packard model 8453 or JASCO V-570 spectrophotometers. IR spectra were performed with a Nicolet Fourier-Transform IR spectrometer in the range $500-4000 \mathrm{~cm}^{-1}$. FAB-MS mass spectra were obtained with a JEOL HX-110 HF double focusing spectrometer operating in the positive ion detection mode. Molar magnetic susceptibility was recorded in the range $5-300 \mathrm{~K}$ on a SQUID system with 10000 Gauss external magnetic field. Electrochemistry was performed with a three-electrode potentiostat $\left(\mathrm{CH}\right.$ Instruments, Model 750A) in $\mathrm{CH}_{2} \mathrm{Cl}_{2}$ deoxygenated by purging with prepurified nitrogen gas. Cyclic voltammetry was conducted with the use of a home-made three-electrode cell equipped with a BAS glassy carbon $\left(0.07 \mathrm{~cm}^{2}\right)$ or platinum $\left(0.02 \mathrm{~cm}^{2}\right)$ disk as the working electrode, a platinum wire as the auxiliary electrode, and a home-made $\mathrm{Ag} / \mathrm{AgCl}$ (saturated) reference electrode. The reference electrode is separated from the bulk solution by a double junction filled with electrolyte solution. Potentials are reported vs. $\mathrm{Ag} / \mathrm{AgCl}$ (saturated) and referenced to the ferrocene/ferrocenium $\left(\mathrm{Fc} / \mathrm{Fc}^{+}\right)$couple which occurs at $E_{1 / 2}=+0.54 \mathrm{~V} v$ s. $\mathrm{Ag} / \mathrm{AgCl}$ (saturated). The working electrode was polished with $0.03 \mu \mathrm{m}$ aluminium on Buehler 
felt pads and was put under ultrasonic radiation for $1 \mathrm{~min}$ prior to each experiment. The reproducibility of individual potential values was within $\pm 5 \mathrm{mV}$. The spectroelectrochemical experiments were accomplished with the use of a $1 \mathrm{~mm}$ cuvette, a 100 mesh platinum gauze as working electrode, a platinum wire as auxiliary electrode, and a $\mathrm{Ag} / \mathrm{AgCl}$ (saturated) reference electrode.

\section{Syntheses}

Preparation of $\mathrm{Ru}_{3}(\mathrm{dpa})_{4}(\mathrm{C} \equiv \mathbf{C F c})_{2} \quad \mathbf{1}$. To a solution of $\mathrm{Ru}_{3}(\mathrm{dpa})_{4} \mathrm{Cl}_{2}(138 \mathrm{mg}, 0.13 \mathrm{mmol})$ in $\mathrm{CH}_{3} \mathrm{CN}(20 \mathrm{ml})$ was added $\mathrm{AgBF}_{4}(38 \mathrm{mg}, 0.29 \mathrm{mmol})$. The mixture was stirred at room temperature for $2 \mathrm{~h}$, and then filtered. $\mathrm{LiC} \equiv \mathrm{CFc}(1.31 \mathrm{mmol})$ in THF $(20 \mathrm{~mL})$ prepared in situ from $\mathrm{HC} \equiv \mathrm{CFc}$ and $\mathrm{CH}_{3} \mathrm{Li}$ was added to the solution. After the mixture was stirred overnight under argon, the solvent was removed under reduced pressure. Crystallization from $\mathrm{CH}_{2} \mathrm{Cl}_{2}$ and hexane produced $77 \mathrm{mg}$ of dark green crystals $(42 \%)$. IR $\left(\mathrm{KBr}, \mathrm{cm}^{-1}\right)$ : 2024.3, 1606.6, 1467.4, 1421 (py); UV/Vis $\left(\mathrm{CH}_{2} \mathrm{Cl}_{2}\right) \lambda_{\max } / \mathrm{nm}\left(\varepsilon / \mathrm{dm}^{3} \mathrm{~mol}^{-1} \mathrm{~cm}^{-1}\right)=$ $278\left(1.23 \times 10^{5}\right), 346\left(5.91 \times 10^{4}\right), 483\left(1.49 \times 10^{4}\right), 765$ $\left(1.97 \times 10^{4}\right) ; \mathrm{MS}(\mathrm{FAB}) \mathrm{m} / z 1403\left(\left[\mathrm{Ru}_{3}(\mathrm{dpa})_{4}(\mathrm{CCFc})_{2}\right]^{+}\right), 1194$ $\left(\left[\mathrm{Ru}_{3}(\mathrm{dpa})_{4}(\mathrm{CCFc})\right]^{+}\right)$. EA( $\left.\%\right) \mathrm{Ru}_{3} \mathrm{Fe}_{2} \mathrm{C}_{64} \mathrm{H}_{50} \mathrm{~N}_{12}$ : calcd. C 54.83, H 3.59, N 11.99; found C 53.21, H 3.76, N 11.83.

Preparation of $\mathrm{Ru}_{3}(\mathrm{dpa})_{4}(\mathrm{C} \equiv \mathbf{C P h})_{2}$ 2. To a solution of $\mathrm{Ru}_{3}(\mathrm{dpa})_{4} \mathrm{Cl}_{2}(46 \mathrm{mg}, 0.044 \mathrm{mmol})$ in $\mathrm{CH}_{3} \mathrm{CN}(10 \mathrm{ml})$ was added $\mathrm{AgBF}_{4}$ (19 mg, $\left.0.096 \mathrm{mmol}\right)$. The mixture was stirred at room temperature for $2 \mathrm{~h}$, and then filtered. $\mathrm{LiC} \equiv \mathrm{CPh}(0.438 \mathrm{mmol})$ in THF $(20 \mathrm{~mL})$ prepared in situ from $\mathrm{HC} \equiv \mathrm{CPh}$ and $\mathrm{CH}_{3} \mathrm{Li}$ was added to the solution. After the mixture was stirred overnight under argon, the solvent was removed under reduced pressure. Crystallization from $\mathrm{CH}_{2} \mathrm{Cl}_{2}$ and hexane produced $15 \mathrm{mg}$ of dark green crystals $(29 \%)$. IR $\left(\mathrm{KBr}, \mathrm{cm}^{-1}\right): 2057,1607,1454$, 1421 (py); UV/Vis $\left(\mathrm{CH}_{2} \mathrm{Cl}_{2}\right) \lambda_{\max } / \mathrm{nm}\left(\varepsilon / \mathrm{dm}^{3} \mathrm{~mol}^{-1} \mathrm{~cm}^{-1}\right)=$ $290\left(1.5 \times 10^{5}\right), 352\left(7.0 \times 10^{4}\right), 490\left(1.44 \times 10^{4}\right), 754$ $\left(2.79 \times 10^{4}\right) ; \mathrm{MS}(\mathrm{FAB}) \mathrm{m} / z 1187\left(\left[\mathrm{Ru}_{3}(\mathrm{dpa})_{4}(\mathrm{CCPh})_{2}\right]^{+}\right), 1086$ $\left(\left[\mathrm{Ru}_{3}(\mathrm{dpa})_{4}(\mathrm{CCPh})\right]^{+}\right)$. EA(\%) $\mathrm{Ru}_{3} \mathrm{C}_{56} \mathrm{H}_{42} \mathrm{~N}_{12}$ : calcd. C 56.7, $\mathrm{H}$ 3.57, N 14.17; found C 55.44, H 3.7, N 13.95.

Preparation of $\left[\mathrm{Ru}_{3}(\mathrm{dpa})_{4}\left(\mathrm{C} \equiv \mathrm{CPhOCH}_{3}\right)_{2}\right]\left(\mathrm{BF}_{4}\right)$ 3. Compound 3 was synthesized using a procedure similar to that for 2 except that $\mathrm{LiC} \equiv \mathrm{CPhOCH}_{3}$ instead of $\mathrm{LiC} \equiv \mathrm{CPh}$ was used. Crystallization from $\mathrm{CH}_{2} \mathrm{Cl}_{2}$ and hexane produced $22 \mathrm{mg}$ of dark green crystals $(40 \%)$. IR $\left(\mathrm{KBr}, \mathrm{cm}^{-1}\right): 2057,1600,1461$, 1428 (py); UV/Vis $\left(\mathrm{CH}_{2} \mathrm{Cl}_{2}\right) \lambda_{\max } / \mathrm{nm}\left(\varepsilon / \mathrm{dm}^{3} \mathrm{~mol}^{-1} \mathrm{~cm}^{-1}\right)=$ $340\left(3.21 \times 10^{4}\right), 465\left(5.56 \times 10^{3}\right), 780\left(2.43 \times 10^{4}\right), 1525$ $\left(2.12 \times 10^{3}\right)$; MS (FAB) $m / z 1247\left(\left[\mathrm{Ru}_{3}(\mathrm{dpa})_{4}\left(\mathrm{CCPhOCH}_{3}\right)_{2}\right]^{+}\right)$, $1116\left(\left[\mathrm{Ru}_{3}(\mathrm{dpa})_{4}\left(\mathrm{CCPhOCH}_{3}\right)\right]^{+}\right) . \mathrm{EA}(\%) \mathrm{Ru}_{3} \mathrm{C}_{58} \mathrm{H}_{46} \mathrm{~N}_{12} \mathrm{O}_{2} \mathrm{BF}_{4}$ : calcd. C 52.26, H 3.48, N 12.61; found C 50.58, H 3.54, N 12.62 .

Preparation of $\left[\mathrm{Ru}_{3}(\mathrm{dpa})_{4}\left(\mathrm{C} \equiv \mathrm{CPhC}_{5} \mathrm{H}_{11}\right)_{2}\right]\left(\mathrm{BF}_{4}\right)$ 4. Compound $\mathbf{4}$ was synthesized using a procedure similar to that for 2 except that $\mathrm{LiC} \equiv \mathrm{CPhC}_{5} \mathrm{H}_{11}$ instead of $\mathrm{LiC} \equiv \mathrm{CPh}$ was used. Crystallization from $\mathrm{CH}_{2} \mathrm{Cl}_{2}$ and hexane produced $19 \mathrm{mg}$ of dark green crystals $(33 \%)$. IR $\left(\mathrm{KBr}, \mathrm{cm}^{-1}\right)$ : 2057, 1607, 1461, 1421 (py); UV/Vis $\left(\mathrm{CH}_{2} \mathrm{Cl}_{2}\right) \lambda_{\max } / \mathrm{nm}\left(\varepsilon / \mathrm{dm}^{3} \mathrm{~mol}^{-1} \mathrm{~cm}^{-1}\right)=345$ $\left(3.54 \times 10^{4}\right), 470\left(6.31 \times 10^{3}\right), 755\left(2.34 \times 10^{4}\right), 1530(1.73 \times$ $\left.10^{3}\right)$; MS (FAB) $m / z 1327\left(\left[\mathrm{Ru}_{3}(\mathrm{dpa})_{4}\left(\mathrm{CCPhC}_{5} \mathrm{H}_{11}\right)_{2}\right]^{+}\right), 1156$ $\left(\left[\mathrm{Ru}_{3}(\mathrm{dpa})_{4}\left(\mathrm{CCPhC}_{5} \mathrm{H}_{11}\right)\right]^{+}\right) . \mathrm{EA}(\%) \mathrm{Ru}_{3} \mathrm{C}_{66} \mathrm{H}_{62} \mathrm{~N}_{12} \mathrm{BF}_{4}$ : calcd. C 56.09, H 4.42, N 11.89; found C 55.39, H 4.57, N 11.61.

Preparation of $\mathrm{Ru}_{3}(\mathrm{dpa})_{4}(\mathrm{C} \equiv \mathbf{C P h C N})_{2} \mathbf{5}$. Compound $\mathbf{5}$ was synthesized using a procedure similar to that for $\mathbf{2}$ except that $\mathrm{LiC} \equiv \mathrm{CPhCN}$ instead of $\mathrm{LiC} \equiv \mathrm{CPh}$ was used. Crystallization from $\mathrm{CH}_{2} \mathrm{Cl}_{2}$ and hexane produced $16 \mathrm{mg}$ of dark green crystals $(30 \%)$. IR $\left(\mathrm{KBr}, \mathrm{cm}^{-1}\right)$ : 2223, 2057, 1600, 1454, 1421 (py); UV/Vis $\left(\mathrm{CH}_{2} \mathrm{Cl}_{2}\right) \lambda_{\max } / \mathrm{nm}\left(\varepsilon / \mathrm{dm}^{3} \mathrm{~mol}^{-1} \mathrm{~cm}^{-1}\right)=274$ $\left(1.17 \times 10^{5}\right), 342\left(1.14 \times 10^{5}\right), 476\left(1.68 \times 10^{4}\right), 755(2.83 \times$ $\left.10^{4}\right)$; $\mathrm{MS}(\mathrm{FAB}) \mathrm{m} / \mathrm{z} 1237\left(\left[\mathrm{Ru}_{3}(\mathrm{dpa})_{4}(\mathrm{CCPhCN})_{2}\right]^{+}\right), 1110$
$\left(\left[\mathrm{Ru}_{3}(\mathrm{dpa})_{4}(\mathrm{CCPhCN})\right]^{+}\right) . \mathrm{EA}(\%) \mathrm{Ru}_{3} \mathrm{C}_{58} \mathrm{H}_{40} \mathrm{~N}_{14}$ : calcd. C 56.35, H 3.26, N 15.86; found C 55.77, H 3.34, N 15.31.

Preparation of $\mathrm{Ru}_{3}(\mathrm{dpa})_{4}\left(\mathrm{C} \equiv \mathrm{CPhNO}_{2}\right)_{2} 6$. Compound 6 was synthesized using a procedure similar to that for $\mathbf{2}$ except that $\mathrm{LiC} \equiv \mathrm{CPhNO}_{2}$ instead of $\mathrm{LiC} \equiv \mathrm{CPh}$ was used. Crystallization from $\mathrm{CH}_{2} \mathrm{Cl}_{2} / 1$,2- $\mathrm{CH}_{2} \mathrm{CH}_{2} \mathrm{Cl}_{2}$ and hexane produced $12.2 \mathrm{mg}$ of dark green crystals $(21 \%)$. IR $\left(\mathrm{KBr}, \mathrm{cm}^{-1}\right)$ : 2050, 1606.6, 1460.8, 1421 (py); UV/Vis $\left(\mathrm{CH}_{2} \mathrm{Cl}_{2}\right) \lambda_{\max } / \mathrm{nm}\left(\varepsilon / \mathrm{dm}^{3} \mathrm{~mol}^{-1} \mathrm{~cm}^{-1}\right)=$ $278\left(9.7 \times 10^{4}\right), 356\left(6.56 \times 10^{4}\right), 480\left(2.12 \times 10^{4}\right), 754$ $\left(2.55 \times 10^{4}\right)$; MS (FAB) $m / z 1277\left(\left[\mathrm{Ru}_{3}(\mathrm{dpa})_{4}\left(\mathrm{CCPhNO}_{2}\right)_{2}\right]^{+}\right)$, $1132\left(\left[\mathrm{Ru}_{3}(\mathrm{dpa})_{4}\left(\mathrm{CCPhNO}_{2}\right)\right]^{+}\right)$. $\mathrm{EA}(\%) \mathrm{Ru}_{3} \mathrm{C}_{56} \mathrm{H}_{40} \mathrm{~N}_{14} \mathrm{O}_{4}$ : calcd. C 52.70, H 3.16, N 15.37; found C 51.94, H 3.22, N 15.16 .

\section{X-Ray crystallographic determinations}

Crystallographic information for $\mathbf{1 - 6}$ is summarized in Tables 1 and 2. The chosen crystals were mounted on a glass fiber. XRay diffraction data for 1-6 were collected at $150 \mathrm{~K}$ on a NONIUS Kappa CCD diffractometer installed with monochromated Mo-K $\alpha$ radiation, $\lambda=0.71073 \AA$. Cell parameters were retrieved and refined using DENZO-SMN software on all observed reflections. ${ }^{9}$ Data reduction was performed with the DENZOSMN software. ${ }^{9}$ An empirical absorption was based on symmetry-equivalent reflections and absorption corrections were applied with the SORTAV program. ${ }^{10}$ All the structures were solved by using SHELXS-97 $7^{11}$ and refined with SHELXL$97^{12}$ by full-matrix least squares on $F^{2}$ values. Hydrogen atoms were fixed at calculated positions and refined using a riding mode.

CCDC reference numbers 270949-270954.

See http://dx.doi.org/10.1039/b506267e for crystallographic data in CIF or other electronic format.

\section{Results and discussion}

\section{Synthesis of $\sigma$-alkynyl complexes}

Early attempts to construct trinuclear metal acetylide complexes were focused on the first row transition metals. The multinuclear complexes of the first row transition metals with acetylide ligands are relatively unstable, this is why examples of trinuclear metal acetylide complexes are rare. ${ }^{13}$ In 1996 we reported the synthesis and structure of the triruthenium complex $\mathrm{Ru}_{3}(\mathrm{dpa})_{4} \mathrm{Cl}_{2}{ }^{7}$ The soft nature of the ruthenium atoms facilitates the synthesis of the acetylide complexes. We first examined the reaction between $\mathrm{Ru}_{3}(\mathrm{dpa})_{4} \mathrm{Cl}_{2}$ and various arylacetylides. However, the reaction resulted in an inseparable mixture of monosubstituted and disubstituted acetylide complexes. Using a procedure similar to those for the diruthenium complexes with alkynyl ligands, ${ }^{14}$ $\mathrm{Ru}_{3}(\mathrm{dpa})_{4} \mathrm{Cl}_{2}$ was first treated with $\mathrm{AgBF}_{4}$ and then reacted with the corresponding arylacetylides to give the desired disubstituted products 1-6 in fair yields. Under the reaction conditions, compounds $1,2,5$, and $\mathbf{6}$ were obtained in the neutral forms, and compounds $\mathbf{3}$ and $\mathbf{4}$ in the one-electron oxidized form. Compounds 1-6 were characterized by various spectroscopic techniques. The IR spectrum of compound $\mathbf{1}$ displays a characteristic band at $2024 \mathrm{~cm}^{-1}$ corresponding to the $\mathrm{C} \equiv \mathrm{C}$ stretching frequency. The mass spectrum shows peaks at $\mathrm{m} / \mathrm{z}$ 1403,1194 , and 985 corresponding to $\left[\mathrm{Ru}_{3}(\mathrm{dpa})_{4}(\mathrm{C} \equiv \mathrm{CFc})_{2}\right]^{+}$, $\left[\mathrm{Ru}_{3}(\mathrm{dpa})_{4}(\mathrm{C} \equiv \mathrm{CFc})\right]^{+}$, and $\left[\mathrm{Ru}_{3}(\mathrm{dpa})_{4}\right]^{+}$, respectively. For compounds 2-6, the IR spectra display characteristic bands $v(\mathrm{C} \equiv \mathrm{C})$ around 2050-2057 $\mathrm{cm}^{-1}$. The absorption spectra of compounds 2-6 show a broad peak in the range between 750 and $770 \mathrm{~nm}$. The broadened bands in the visible region may be ascribed to the charge-transfer transitions of axial ligand to metal..$^{14,15}$

\section{Structural results}

Crystals of 1 were obtained from $\mathrm{CH}_{2} \mathrm{Cl}_{2}$ solution layered with hexane. The molecular structure was further confirmed by X-ray diffraction analysis. As shown in Fig. 1, the linear 

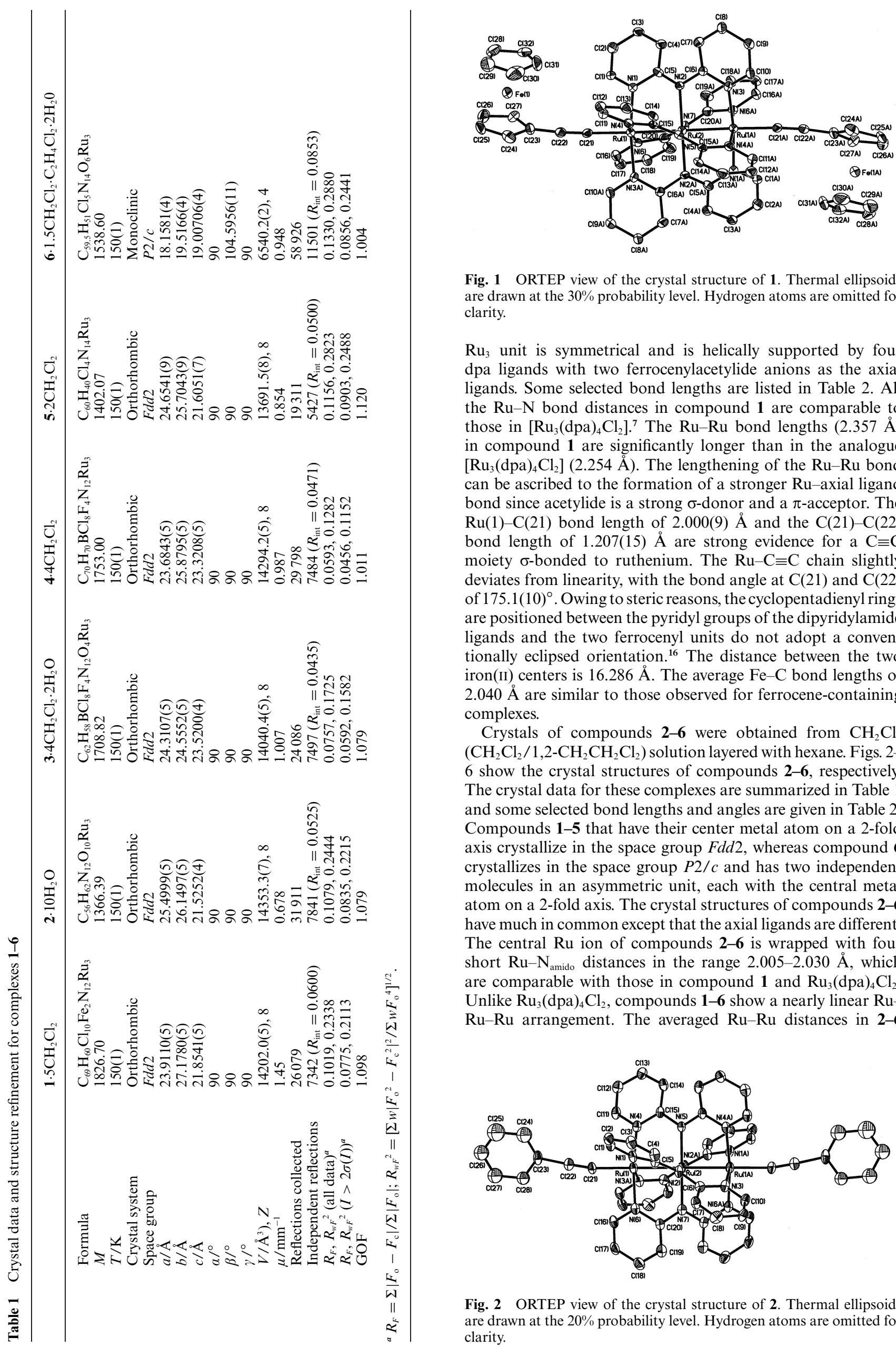

Fig. 1 ORTEP view of the crystal structure of 1 . Thermal ellipsoids are drawn at the $30 \%$ probability level. Hydrogen atoms are omitted for clarity.

$\mathrm{Ru}_{3}$ unit is symmetrical and is helically supported by four dpa ligands with two ferrocenylacetylide anions as the axial ligands. Some selected bond lengths are listed in Table 2. All the $\mathrm{Ru}-\mathrm{N}$ bond distances in compound $\mathbf{1}$ are comparable to those in $\left[\mathrm{Ru}_{3}(\mathrm{dpa})_{4} \mathrm{Cl}_{2}\right]^{7}{ }^{7}$ The $\mathrm{Ru}-\mathrm{Ru}$ bond lengths $(2.357 \AA)$ in compound $\mathbf{1}$ are significantly longer than in the analogue $\left[\mathrm{Ru}_{3}(\mathrm{dpa})_{4} \mathrm{Cl}_{2}\right](2.254 \AA)$. The lengthening of the $\mathrm{Ru}-\mathrm{Ru}$ bond can be ascribed to the formation of a stronger $\mathrm{Ru}-$ axial ligand bond since acetylide is a strong $\sigma$-donor and a $\pi$-acceptor. The $\mathrm{Ru}(1)-\mathrm{C}(21)$ bond length of $2.000(9) \AA$ and the $\mathrm{C}(21)-\mathrm{C}(22)$ bond length of 1.207(15) $\AA$ are strong evidence for a $\mathrm{C} \equiv \mathrm{C}$ moiety $\sigma$-bonded to ruthenium. The $\mathrm{Ru}-\mathrm{C} \equiv \mathrm{C}$ chain slightly deviates from linearity, with the bond angle at $C(21)$ and $C(22)$ of $175.1(10)^{\circ}$. Owing to steric reasons, the cyclopentadienyl rings are positioned between the pyridyl groups of the dipyridylamide ligands and the two ferrocenyl units do not adopt a conventionally eclipsed orientation. ${ }^{16}$ The distance between the two iron(II) centers is $16.286 \AA$. The average $\mathrm{Fe}-\mathrm{C}$ bond lengths of $2.040 \AA$ are similar to those observed for ferrocene-containing complexes.

Crystals of compounds 2-6 were obtained from $\mathrm{CH}_{2} \mathrm{Cl}_{2}$ $\left(\mathrm{CH}_{2} \mathrm{Cl}_{2} / 1,2-\mathrm{CH}_{2} \mathrm{CH}_{2} \mathrm{Cl}_{2}\right)$ solution layered with hexane. Figs. 26 show the crystal structures of compounds 2-6, respectively. The crystal data for these complexes are summarized in Table 1 and some selected bond lengths and angles are given in Table 2 . Compounds 1-5 that have their center metal atom on a 2-fold axis crystallize in the space group $F d d 2$, whereas compound 6 crystallizes in the space group $P 2 / c$ and has two independent molecules in an asymmetric unit, each with the central metal atom on a 2-fold axis. The crystal structures of compounds 2-6 have much in common except that the axial ligands are different. The central $\mathrm{Ru}$ ion of compounds 2-6 is wrapped with four short $\mathrm{Ru}-\mathrm{N}_{\text {amido }}$ distances in the range 2.005-2.030 $\AA$, which are comparable with those in compound 1 and $\mathrm{Ru}_{3}(\mathrm{dpa})_{4} \mathrm{Cl}_{2}$. Unlike $\mathrm{Ru}_{3}(\mathrm{dpa})_{4} \mathrm{Cl}_{2}$, compounds $\mathbf{1}-\mathbf{6}$ show a nearly linear $\mathrm{Ru}-$ $\mathrm{Ru}-\mathrm{Ru}$ arrangement. The averaged $\mathrm{Ru}-\mathrm{Ru}$ distances in 2-6

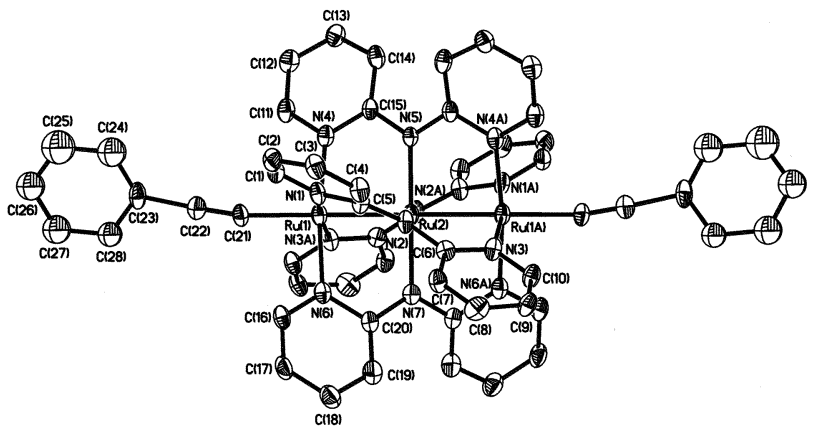

Fig. 2 ORTEP view of the crystal structure of 2. Thermal ellipsoids are drawn at the $20 \%$ probability level. Hydrogen atoms are omitted for clarity. 
Table 2 Selected bond distances $(\AA)$ and angles $\left(^{\circ}\right)$ for complexes $\mathrm{Ru}_{3}(\mathrm{dpa})_{4} \mathrm{Cl}_{2}{ }^{7}$ and $\mathbf{1 - 6}$

\begin{tabular}{|c|c|c|c|c|c|c|c|}
\hline & $\mathrm{Ru}_{3}(\mathrm{dpa})_{4} \mathrm{Cl}_{2}^{7}$ & 1 & 2 & 3 & 4 & 5 & $6^{a}$ \\
\hline $\mathrm{Ru}(1)-\mathrm{Cl}$ & \multirow{3}{*}{$\begin{array}{l}2.596(2) \\
2.25375(5)\end{array}$} & \multirow{3}{*}{$2.3568(6)$} & \multirow{3}{*}{$2.3497(5)$} & \multirow{3}{*}{$2.3572(5)$} & \multirow{3}{*}{$2.3520(4)$} & \multirow{3}{*}{$2.3304(9)$} & \\
\hline $\mathrm{Ru}(1)-\mathrm{Ru}(2)$ & & & & & & & $2.3445(7)$ \\
\hline $\mathrm{Ru}(3)-\mathrm{Ru}(4)$ & & & & & & & $2.3534(8)$ \\
\hline $\mathrm{Ru}(1)-\mathrm{N}$ & \multirow[t]{2}{*}{$2.108(6)$} & \multirow[t]{2}{*}{$2.104(8)$} & \multirow[t]{2}{*}{$2.104(8)$} & \multirow[t]{2}{*}{$2.111(6)$} & \multirow[t]{2}{*}{$2.105(4)$} & \multirow[t]{2}{*}{$2.122(13)$} & $2.106(9)$ \\
\hline $\mathrm{Ru}(3)-\mathrm{N}$ & & & & & & & $2.111(10)$ \\
\hline $\mathrm{Ru}(2)-\mathrm{N}$ & \multirow[t]{6}{*}{$2.066(6)$} & \multirow[t]{2}{*}{$2.034(12)$} & \multirow[t]{2}{*}{$2.024(12)$} & \multirow[t]{2}{*}{$2.022(8)$} & \multirow[t]{2}{*}{$2.030(6)$} & \multirow[t]{2}{*}{$2.005(19)$} & $2.027(12)$ \\
\hline $\mathrm{Ru}(4)-\mathrm{N}$ & & & & & & & $2.019(12)$ \\
\hline $\mathrm{Ru}(1)-\mathrm{C}$ & & \multirow{2}{*}{$2.000(9)$} & \multirow{2}{*}{$2.031(7)$} & \multirow{2}{*}{$2.038(6)$} & \multirow{2}{*}{$2.019(5)$} & \multirow[t]{2}{*}{$1.965(13)$} & $1.996(11)$ \\
\hline $\mathrm{Ru}(3)-\mathrm{C}$ & & & & & & & $2.017(11)$ \\
\hline $\mathrm{C}(21)-\mathrm{C}(22)$ & & \multirow[t]{2}{*}{$1.207(15)$} & \multirow[t]{2}{*}{$1.141(9)$} & \multirow[t]{2}{*}{$1.180(9)$} & \multirow[t]{2}{*}{$1.202(7)$} & \multirow[t]{2}{*}{$1.229(15)$} & $1.234(15)$ \\
\hline $\mathrm{C}(49)-\mathrm{C}(50)$ & & & & & & & $1.195(13)$ \\
\hline $\mathrm{Ru}(1)-\mathrm{Ru}(2)-\mathrm{Ru}(1 \mathrm{~A})$ & \multirow[t]{2}{*}{$171.15(4)$} & \multirow[t]{2}{*}{ 179.61(7) } & \multirow[t]{2}{*}{$179.87(7)$} & \multirow[t]{2}{*}{$179.75(4)$} & \multirow[t]{2}{*}{$179.75(3)$} & \multirow[t]{2}{*}{$179.83(10)$} & $178.35(7)$ \\
\hline $\mathrm{Ru}(3)-\mathrm{Ru}(4)-\mathrm{Ru}(3 \mathrm{~B})$ & & & & & & & $179.49(8)$ \\
\hline
\end{tabular}

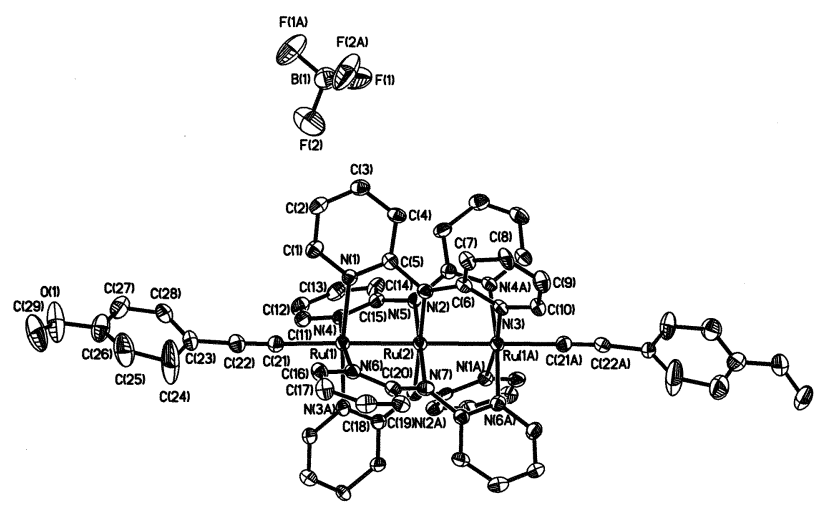

Fig. 3 ORTEP view of the crystal structure of 3 . Thermal ellipsoids are drawn at the $30 \%$ probability level. Hydrogen atoms are omitted for clarity.

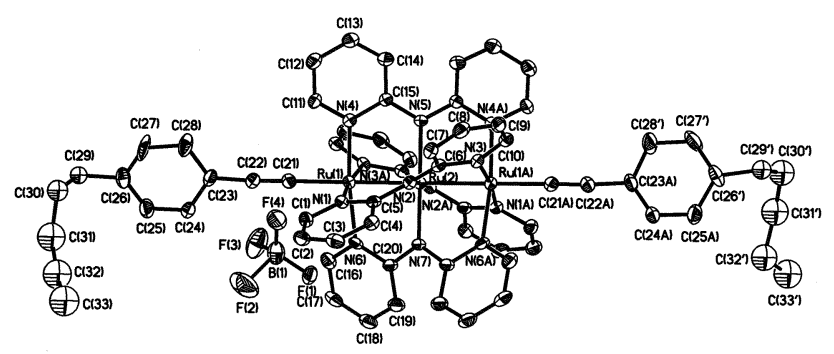

Fig. 4 ORTEP view of the crystal structure of 4 . Thermal ellipsoids are drawn at the $30 \%$ probability level. Hydrogen atoms are omitted for clarity.

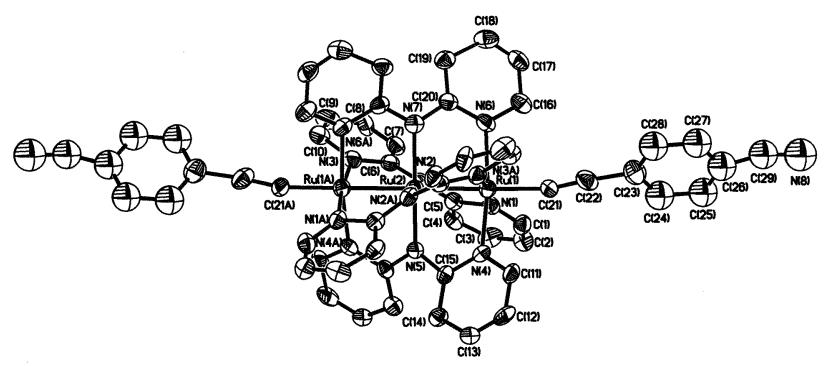

Fig. 5 ORTEP view of the crystal structure of $\mathbf{5}$. Thermal ellipsoids are drawn at the $20 \%$ probability level. Hydrogen atoms are omitted for clarity.

are 2.3497(5), 2.3572(5), 2.3520(4), 2.3304(9), and 2.3445(7) A, respectively. The slight lengthening of the $\mathrm{Ru}-\mathrm{Ru}$ distances in $\mathbf{3}$ and $\mathbf{4}$ is attributed to the electron-donating nature of the para substituents. However, it is possible that the repulsion

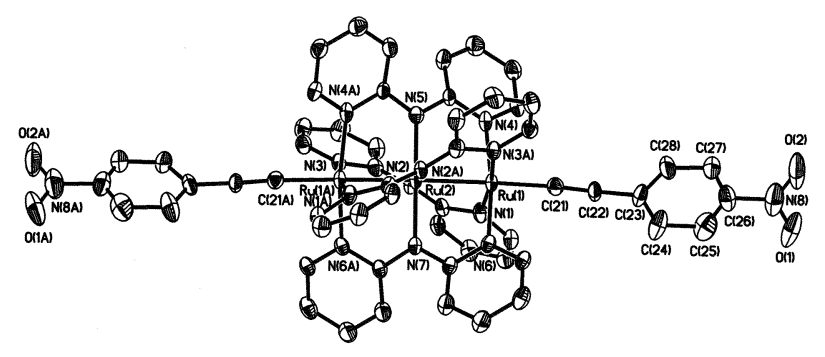

Fig. 6 ORTEP view of the crystal structure of one of the two independent molecules of $\mathbf{6}$. Thermal ellipsoids are drawn at the $30 \%$ probability level. Hydrogen atoms are omitted for clarity.

between the ruthenium ions increases as the oxidation state of the triruthenium core increases. This results in lengthening of the metal-metal bond. The $\mathrm{Ru}(1)-\mathrm{C}(21)$ bond lengths are longer in $\mathbf{3}$ and $\mathbf{4}$ than those in $\mathbf{5}$ and $\mathbf{6}$, while the $\mathrm{C}(21)-\mathrm{C}(22)$ bond distances are shorter in $\mathbf{3}$ and $\mathbf{4}$ than those in $\mathbf{5}$ and $\mathbf{6}$. This can be explained by the stronger $\pi$-back donation resulting from the electron-withdrawing nature of the $\mathrm{CN}$ and $\mathrm{NO}_{2}$ groups.

\section{Electrochemistry}

It is well known that ruthenium complexes have various oxidation states. Thus, rich redox chemistry for our triruthenium complexes is expected and it is desirable to study the electrochemical properties of these complexes. Fig. 7 shows one of their cyclic voltammograms in $\mathrm{CH}_{2} \mathrm{Cl}_{2}$ containing $0.1 \mathrm{M}$ TBAP. All these complexes exhibit three one-electron redox couples: two oxidations $\left(E_{\mathrm{ox} 1}\right.$ and $\left.\mathrm{E}_{\mathrm{ox} 2}\right)$ and one reduction $\left(E_{\mathrm{red}}\right)$. The electrochemical data are summarized in Table 3.

To evaluate the electron conduction capability, the electronic communication between the two ferrocenyl units was studied using electrochemical techniques. As shown in Fig. 8, the cyclic voltammagram of compound $\mathbf{1}$ displays three reversible redox couples. Fig. 9 shows the spectral changes for the oxidations of compound 1. Upon one and two electron oxidations, the

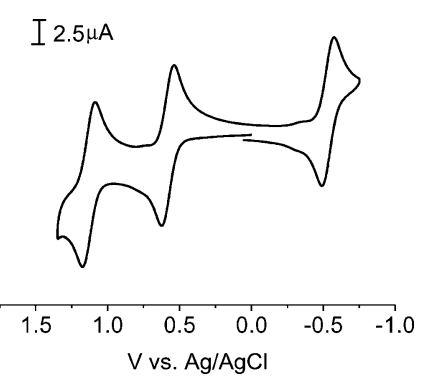

Fig. 7 Cyclic voltammogram of $1.0 \mathrm{mM}$ compound 3 in $\mathrm{CH}_{2} \mathrm{Cl}_{2}$ at $0.1 \mathrm{~V} \mathrm{~s}^{-1}$ with $0.1 \mathrm{M}$ TBAP. 
Table 3 Redox potentials and $\sigma$ values for compounds 2-6

\begin{tabular}{lclll}
\hline Compound & $\sigma_{\mathrm{Y}}{ }^{a}$ & $E_{1 / 2}(\mathrm{Ox} 2) / \mathrm{V}$ & $E_{1 / 2}(\mathrm{Ox} 1) / \mathrm{V}$ & $E_{1 / 2}(\mathrm{Red}) / \mathrm{V}$ \\
\hline $\mathbf{2}$ & 0 & 1.249 & 0.643 & -0.492 \\
$\mathbf{3}$ & -0.27 & 1.145 & 0.600 & -0.517 \\
$\mathbf{4}$ & -0.15 & 1.219 & 0.633 & -0.497 \\
$\mathbf{5}$ & 0.66 & 1.351 & 0.722 & -0.369 \\
$\mathbf{6}$ & 0.78 & 1.352 & 0.723 & -0.355
\end{tabular}

${ }^{a}$ Taken from ref. 22 .
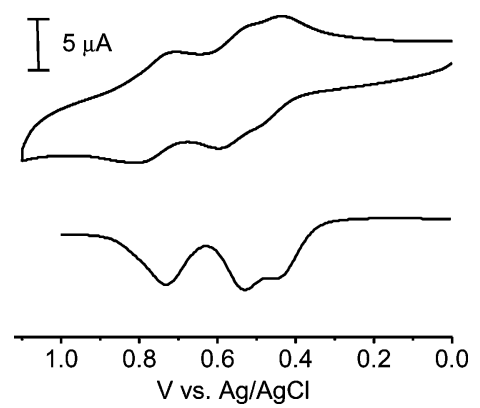

Fig. 8 Cyclic voltammogram (top) and differential pulse voltammogram (bottom) of $0.5 \mathrm{mM}$ compound 1 in $\mathrm{CH}_{2} \mathrm{Cl}_{2}$ at $0.1 \mathrm{~V} \mathrm{~s}^{-1}$ with 0.1 M TBAP

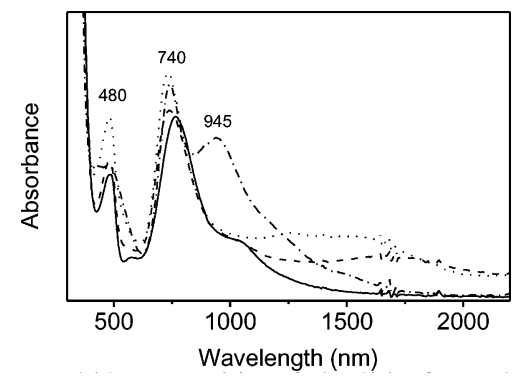

Fig. 9 UV/Vis/Near IR spectral changes for the oxidation of compound 1 in $\mathrm{CH}_{2} \mathrm{Cl}_{2}$ with $0.1 \mathrm{M}$ TBAP at applied potentials of +0.20 (solid), +0.48 (dash), +0.65 (dot), and $+0.90 \mathrm{~V}$ (dash dot).

broad band in the near IR region corresponds to the charge transfer between ferrocene units and from the $\mathrm{Ru}_{3}$ unit to the oxidized ferrocene. In the case of compounds $\mathbf{2}-\mathbf{6}$, no peaks are observed in the near IR region upon oxidation. The $\mathrm{Ru}_{3}$-centered $\left(\left[\mathrm{Ru}_{3}\right]^{7+} /\left[\mathrm{Ru}_{3}\right]^{6+}\right)$ redox reaction occurs at $E_{1 / 2}=+0.76 \mathrm{~V}$, which is higher than those of analogues $\left[\mathrm{Ru}_{3}(\mathrm{dpa})_{4}(\mathrm{CCAr})_{2}\right]$ $\left(E_{1 / 2}=+0.60-+0.72 \mathrm{~V}\right)$. This is attributed to the increased electron withdrawing ability of the ferrocence axial ligands upon oxidation. The stepwise one-electron oxidations instead of a two-electron oxidation are indicative of electronic coupling between the two iron centers, suggesting that the bridge may provide a passive path for electrons. These reversible waves for the ferrocenyl units are resolved by using differential-pulse techniques. The comproportionation constant $K_{\mathrm{c}}$ is calculated to be about $33 .{ }^{17}$ This is larger than for the corresponding tricobalt complex $\left(K_{\mathrm{c}}=16\right)$ in which the $\mathrm{Co}_{3}$ unit is unsymmetrical ${ }^{18}$ and an overall bond order of 1.5 over the $\mathrm{Co}_{3}$ unit is estimated. As compared to the diruthenium complex with ferrocenylacetylide axial ligands, ${ }^{14 b}$ the electronic coupling of our system is weaker due to the longer $\mathrm{Fe}-\mathrm{Fe}$ distance. Complex $\mathbf{1}$ can be classified as a weakly coupled (class II) mixed-valence system, and is comparable to the $\alpha, \omega$-dipyridylpolyene molybdenum complex $\left[\mathrm{Mo}\left(4,4^{\prime}-\mathrm{NC}_{5} \mathrm{H}_{4}(\mathrm{CH}=\mathrm{CH})_{4} \mathrm{H}_{4} \mathrm{C}_{5} \mathrm{~N}\right) \mathrm{Mo}\right]$ and the polyyne rhenium complex $\left[\mathrm{ReC}_{16} \mathrm{Re}\right] .^{19}$

Compounds 2-6 exhibit similar electrochemical properties. As summarized in Table 3, all these complexes exhibit three reversible redox couples and these electrochemical reactions involve one electron transfer as ascertained by spectroelectrochemistry. ${ }^{20}$ The redox potentials of all three electron transfer processes shift cathodically as the electron-donating ability of the para substituents increases. Hammett constants provide an approximate measure of substituent effects in para positions relative to the triruthenium core. ${ }^{21}$ According to the following equation: ${ }^{22} E_{1 / 2}(\mathrm{Y})=E_{1 / 2}(\mathrm{H})+\rho\left(2 \sigma_{\mathrm{Y}}\right)$, where $\rho$ is the reactivity constant, a plot of $E_{1 / 2}$ for the $E_{\text {ox } 1}, E_{\text {ox } 2}$, and $E_{\text {red }}$ couples $v s$. the sum of the Hammett constants for the different substituents is shown in Fig. 10. The reactivity constants are $93(R=95.1 \%)$, $62(R=97.0 \%)$, and $84 \mathrm{mV}(R=99.6 \%)$ for the two oxidations and one reduction, respectively. The linear relationship reflects the electron density on the triruthenium center related to the electron-withdrawing and electron-donating ability of the substituents. For example, when the $\mathrm{OCH}_{3}$ group is replaced by the more electron-withdrawing $\mathrm{NO}_{2}$ group, the electron density on the triruthenium unit is reduced considerably and this results in a higher redox potential.

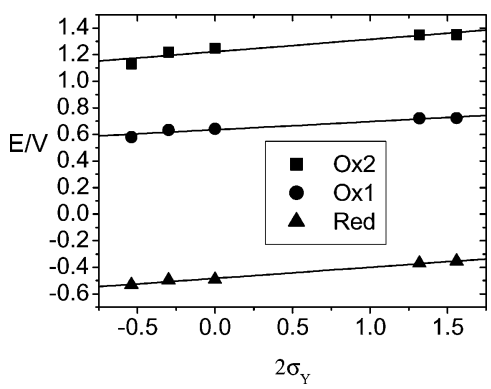

Fig. 10 Hammett plot of $E_{1 / 2} v s .2 \sigma$. The squares $(\square)$ are the measured values of $E_{1 / 2}(\mathrm{Ox} 2)$, circles $(-)$ are the measured values of $E_{1 / 2}(\mathrm{Ox} 1)$, triangles $(\boldsymbol{\Delta})$ are the measured values of $E_{1 / 2}(\mathrm{Red})$, and the solid lines are the least-squares fit.

Tong et al. reported the structures and eletrochemical properties of a series of diruthenium acetylide complexes $\mathrm{Ru}_{2}(\mathrm{DMBA})_{4}(\mathrm{C} \equiv \mathrm{CAr})_{2}$, where DMBA is $N, N^{\prime}-$ dimethylbenzamidinate and $\mathrm{C} \equiv \mathrm{CAr}$ is arylacetylide. The reactivity constants of these complexes are 110 and $86 \mathrm{mV}$ for the oxidation and reduction processes, respectively. ${ }^{14 a}$ Our triruthenium acetylide complexes exhibit comparable reactivity constants to the diruthenium system.

\section{Bonding and magnetic properties}

According to theoretical calculations, the electronic configuration of the $\mathrm{Ru}_{3}$ unit in $\left[\mathrm{Ru}_{3}(\mathrm{dpa})_{4} \mathrm{Cl}_{2}\right]$ is described as $\sigma^{2} \pi^{4} \delta^{2} \pi_{\mathrm{nb}}{ }^{4} \delta_{\mathrm{nb}}{ }^{2} \delta^{* 2} \sigma_{\mathrm{nb}}{ }^{2}$, thus resulting in the diamagnetism of the complex and a bond order of three over the $\mathrm{Ru}_{3}$ unit, i.e., a bond order of 1.5 between adjacent ruthenium ions. While replacing axial ligands from chloride to the stronger $\pi$-acid groups (acetylide, cyanide. . etc), the electronic configuration of the $\mathrm{Ru}_{3}$ unit in $\left[\mathrm{Ru}_{3}(\mathrm{dpa})_{4} \times_{2}\right]$ transforms to $\sigma^{2} \pi^{4} \delta^{2} \pi_{\mathrm{nb}}{ }^{4} \delta_{\mathrm{nb}}{ }^{2} \delta^{* 2} \pi^{* 2}$, resulting in two unpaired electrons of the complex and a bond order of two over the $\mathrm{Ru}_{3}$ unit, i.e. a bond order of 1 between adjacent ruthenium ions. ${ }^{23}$ As shown in Scheme 2, the strong $\pi$-back donation results in a decrease in the energy level of the $\pi^{*}$ orbitals. Fig. 11 shows that the effective magnetic moment of $2.82 \mu_{\mathrm{B}}$ at $300 \mathrm{~K}$ in compound 2 indicates that the triruthenium

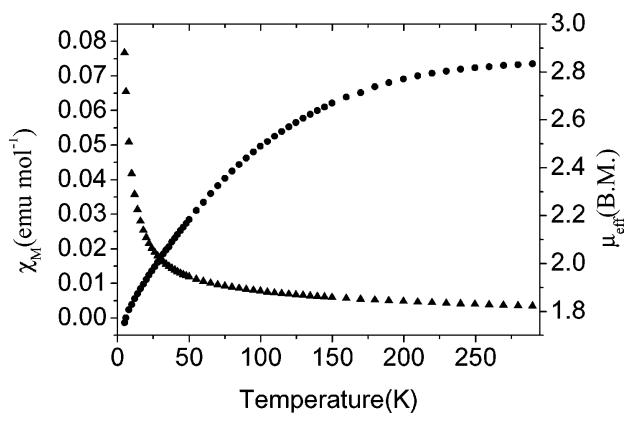

Fig. 11 Temperature-dependent magnetic effective moment ( $(\mathbf{)})$ and the molar magnetic susceptibility $(\boldsymbol{\Delta})$ for compound $\mathbf{2}$. 


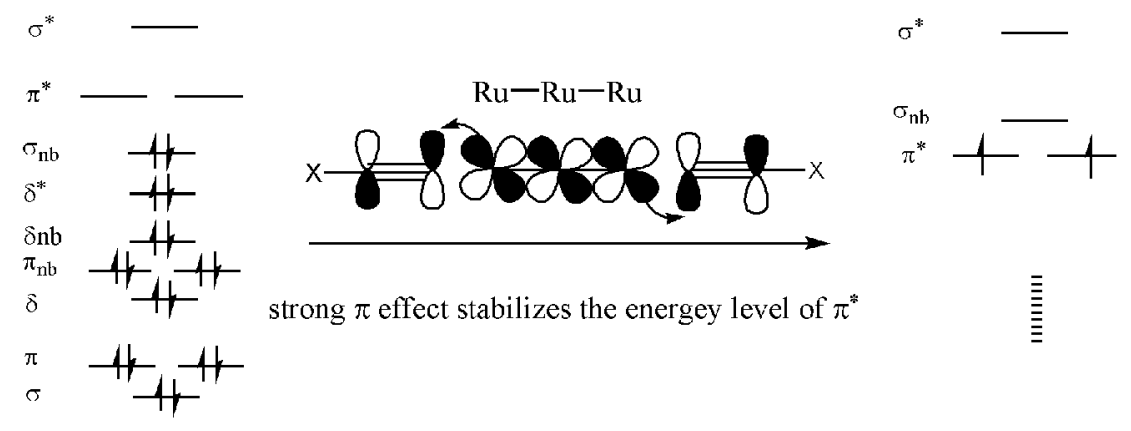

M.O. of dichloride adducts

M.O. of diacetylide adducts

Scheme 2

acetylide complex is paramagnetic with two unpaired electrons and this is consistent with theoretical calculations. For compounds 3 and $\mathbf{4}$, the values of $\mu_{\text {eff }}$ are 3.78 and $3.74 \mu_{\mathrm{B}}$, respectively. This indicates that the electron is removed from the $\delta^{*}$ orbital upon one electron oxidation and there are three unpaired electrons for the oxidized complexes. Due to the metalaxial ligand interactions of the stronger $\pi$-acid groups, a bond order of three over the $\mathrm{Ru}_{3}$ unit in $\mathrm{Ru}_{3}(\mathrm{dpa})_{4} \mathrm{Cl}_{2}$ is reduced to two over the $\mathrm{Ru}_{3}$ unit in $\mathrm{Ru}_{3}(\mathrm{dpa})_{4}(\mathrm{C} \equiv \mathrm{CPhX})_{2}$ (see Scheme 2). The $\mathrm{Ru}-\mathrm{Ru}$ bond lengths in compounds 1-6(2.330-2.357 $\mathrm{A})$ are longer than that in $\mathrm{Ru}_{3}(\mathrm{dpa})_{4} \mathrm{Cl}_{2}(2.254 \AA)$. It is ascribed to the stronger $\pi$-backbonding from metal to ligand.

\section{Conclusion}

A series of novel triruthenium adducts comprised of a linear triruthenium core and acetylide have been synthesized in a facile way. Compound $\mathbf{1}$ is the first example of a triruthenium system incorporating ferrocene entities with $\pi$-conjugation. The electrochemical data show that the molecule exhibits electronic communication between the redox sites via the triruthenium unit.

The results shed light on the use of these molecules as "molecular wires". Longer multinuclear metal complexes with various redox ligands will allow us detailed investigations of their efficiency for electron or hole conducting. In compounds $\mathbf{2 - 6}$, the redox properties of the triruthenium core can be finetuned by the para substituent of the arylacetylide and these complexes exhibit a linear $E_{1 / 2}-\sigma$ relationship. By employing similar conditions, a new type of one dimensional polymer composed of a trinuclear unit and diacetylide bridge may be synthesized. Work along this line is in progress in our laboratory.

\section{Acknowledgements}

The authors acknowledge the National Science Council and Ministry of Education of Taiwan for financial support. We also thank Professor Kuan-Jiuh Lin for the access of UV-Vis-Near IR spectrometer.

\section{References}

1 F. Paul, J. Y. Mevellec and C. Lapinte, J. Chem. Soc., Dalton Trans., 2002, 1783 and references cited therein.

2 S. K. Hurst and T. Ren, J. Organomet. Chem., 2003, 670, 188 and references cited therein.

3 H. C. Chang, J. T. Li, C. C. Wang, T. W. Lin, H. C. Lee, G. H. Lee and S. M. Peng, Eur. J. Inorg. Chem., 1999, 1243; S. Y. Lai, T. W. Lin, Y. H. Chen, C. C. Wang, G. H. Lee, M. H. Yang, M. K. Leung and S. M. Peng, J. Am. Chem. Soc., 1999, 121, 250; S. J. Shieh,
C. C. Chou, G. H. Lee, C. C. Wang and S. M. Peng, Angew. Chem. Int. Ed. Engl., 1997, 36, 56; C. Y. Yeh, C. H. Chou, K. C. Pan, C. C. Wang, G. H. Lee, Y. O. Su and S. M. Peng, J. Chem. Soc., Dalton Trans., 2002, 2670; C. Y. Yeh, Y. L. Chiang, G. H. Lee and S. M. Peng, Inorg. Chem., 2002, 41, 4096; S. M. Peng, C. C. Wang, Y. L. Jang, Y. H. Chen, F. Y. Li, C. Y. Mou and M. K. Leung, J. Magn. Magn. Mater., 2000, 209, 80.

4 R. Clérac, F. A. Cotton, L. M. Danniels, K. M. Dunbar, C. A. Murillo and I. Pascual, Inorg. Chem., 2000, 39, 752; J. F. Berry, F. A. Cotton, L. M. Danniels and C. A. Murillo, J. Am. Chem. Soc., 2002, 124, 3212; J. F. Berry, F. A. Cotton, P. Lei, T. Lu and C. A. Murillo, Inorg. Chem., 2003, 42, 3534.

5 S. Y. Lin, I. W. P. Chen, C. H. Chen, M. H. Hsieh, C. Y. Yeh, T. W. Lin, Y. H. Chen and S. M. Peng, J. Phys. Chem. B, 2004, 108, 959.

6 J. P. Launay, Chem. Soc. Rev., 2001, 30, 386 and references cited therein.

7 J. T. Sheu, C. C. Lin, I. Chao, C. C. Wang and S. M. Peng, Chem. Commun., 1996, 315.

8 S. Takahashi, Y. Kuroyama, K. Sonogashira and N. Hagihara, Synthesis, 1980, 8, 627.

9 Z. Otwinowski and W. Minor, Processing of X-ray Diffraction Data Collected in Oscillation Mode, Methods in Enzymology, ed. C. W. Carter and R. M. Sweet, Jr., Academic Press, New York, 1997, vol. 276.

10 R. H. Blessing, Acta Crystallogr., Sect. A, 1995, 51, 33.

11 G. M. Sheldrick, Acta Crystallogr., Sect. A, 1990, 46, 467.

12 G. M. Sheldrick, SHELXL-97, Program for the Refinement of Crystal Structures, University of Göttingen, Germany, 1997.

13 J. F. Berry, F. A. Cotton and C. A. Murillo, Dalton Trans., 2003, 3015; J. F. Berry, F. A. Cotton, C. A. Murillo and B. K. Roberts, Inorg. Chem., 2004, 43, 2277.

14 (a) K. Stephanie, G. L. Xu and T. Ren, Organometallics., 2003, 22, 4118; (b) G. L. Xu, M. C. DeRosa, R. J. Crutchley and T. Ren, J. Am. Chem. Soc., 2004, 126, 3728; (c) G. L. Xu, G. Zou, Y. H. Ni, M. C. DeRosa, R. J. Crutchley and T. Ren, J. Am. Chem. Soc., 2003, 125, 10057; Y. Shi, G. T. Yee, G. Wang and T. Ren, J. Am. Chem. Soc., 2004, 126, 10552.

15 G. L. Xu, C. Campana and T. Ren, Inorg. Chem., 2002, 41, 3521.

16 M. C. B. Colbert, J. Lewis, N. J. Long, P. R. Raithby, A. J. P. White and D. J. Williams, J. Chem. Soc., Dalton Trans., 1997, 99.

17 D. E. Richardson and H. Taube, Inorg. Chem., 1981, 20, 1278.

18 J. F. Berry, F. A. Cotton and C. A. Murillo, Organometallics, 2004, 23, 2503.

19 S. L. W. McWhinnie, J. A. Thomas, T. A. Hamor, C. J. Jones, J. A. McCleverty, D. Collison, F. E. Mabbs, C. J. Harding, L. J. Yellowlees and M. G. Hutchings, Inorg. Chem., 1996, 35, 760; R. Dembinski, T. Bartik, B. Bartik, M. Jaeger and J. A. Gladysz, J. Am. Chem. Soc., 2000, 122, 810 .

20 D. F. Rohrbach, E. Deutsch, W. R. Heineman and R. F. Pasternack, Inorg. Chem., 1977, 16, 2650.

21 Most physical organic textbooks discuss Hammett constants. An excellent source is: T. H. Lowry and K. S. Richardson, Physical Organic Chemistry, Harper and Row, New York, 1976.

22 C. Hansch, A. Leo and R. W. Taft, Chem. Rev., 1991, 91, 165.

23 C.-K. Kuo, P.-C. Liu, C.-Y. Yeh, C.-H. Chou, T.-B. Tsao, G.-H. Lee, S.-M. Peng, M.-M. Rohmer and M. Bérnard, manuscript in preparation. 